\title{
Espaço, Humano \\ e Sagrado no \\ Candomblé
}

\author{
Felipe Ibiapina, Lúcia Leitão*
}

Resumo O ensaio busca discutir a relação entre o espaço arquitetônico, o humano e o sagrado no Candomblé, a fim de compreender o papel assumido pela arquitetura nesta tríade. O artigo é produto da pesquisa de doutorado do autor, ainda em curso, desenvolvida no âmbito interdisciplinar da arquitetura e antropologia afro-brasileira. Por ter sido elaborado antes da pesquisa de campo, baseia-se no marco teórico levantado, adotando, como perspectiva epistemológica, o diálogo entre a filosofia ocidental, a partir de uma leitura de Heidegger, e a filosofia nagô, sistematizada por Muniz Sodré. O ensaio intenta contribuir com os estudos afro-brasileiros na Arquitetura, discutindo o terreiro de candomblé enquanto objeto legítimo desta área do conhecimento, uma abertura para a alteridade, além do racionalismo ocidental.

Palavras-chave: arquitetura, afro-brasileiro, religião.

\section{Espacio, Humano y Sagrado en Candomblé}

Resumen Él artículo busca discutir la relación entre el espacio arquitectónico, el humano y lo sagrado en Candomblé, con el objectivo de entender la posición de la arquitectura en esta tríade. El artículo es producto de la pesquisa de doctorado del autor, en proceso, desarrollada en ámbito interdisciplinar de la arquitectura y la antropologia afro-brasileña. Cómo se hizo antes de la investigación de campo, es basado en marco teórico, adoptando como perspectiva epistemológica el dialogo entre la phylosofia ocidental, mediante una lectura de Heidegger, y la phylosofia nagô, sistematizada por Muniz Sodré. Él artículo intenta contribuir con los estudios afro-brasileños en la Arquitectura, discutiendo el terreiro de candomblé, constituyendo una abertura a la alteridad, más allá del racionalismo ocidental.

\section{Space, Human and the Sacred in Candomblé}

Abstract The essay seeks to discuss the relationship between the architectural space, human and the sacred in Candomblé, in order to understand the role assumed by architecture in this triad. The pape is a preliminar thesis result, that is in course, and before the field research. The basis adopted was the teoric mark, using as a epistemological perspective the dialogue between the western philosophy throw Heidegger and yoruba philosophy, organized by Muniz Sodré. The essay intents contribute with afro-brazilian studies into Arquitecture, legitimating the candomblé's temple as a architecture object of study, opening this field for alterity, further the western racionalism.

Key words: architecture, afrobrazilian, religion.

Palabras clave: arquitectura, afro-brasileño, religión. 
0

candomblé é uma das religiões de matriz africana que cultuam os orixás, divindades do panteão africano iorubá que regem elementos da natureza. De origem brasileira, a religião está ancorada na ancestralidade advinda da diáspora negra, "por meio da herança cultural, religiosa e filosófica trazida pelos africanos que foram escravizados" (BARROS, 2009). Esta religião é ontologicamente heterogênea, uma vez que surge do intercâmbio de etnias distintas. Não existe um purismo, mas, imbricações oriundas dos contatos interétnicos, ocorridos sobretudo no Brasil, resultando no cruzamento de nações: Ketu-Nagô (Iorubá); ljexá (Iorubá); Jeje (Fon); Angola (Bantu); Congo (Bantu); Angola-Congo (Bantu) (LODY, 2006).

Uma das estratégias do poder escravocrata para coibir motins e insurreição dos escravizados era misturar pessoas de grupos étnicos diferentes, dificultando a articulação entre as mesmas, sobretudo pelas barreiras linguísticas e culturais. Não obstante a desterritorialização compulsória, o mecanismo de segregação cultural veio para reforçar o intento dos escravocratas de reificar o negro escravizado.

Todavia, apesar desta trama complexa que dificultava a construção identitária dos afrodescendentes e afro-brasileiros, se estruturou o candomblé como fenômeno de resistência. O candomblé, além de constituir um sistema simbólico religioso, é mantenedor da memória e do patrimônio das etnias africanas procedentes, contribuindo para a formação de uma identidade afro-brasileira (LODY, 2006).

Diante do exposto, este ensaio se propõe a investigar a construção identitária do(a) iniciado (a) no culto do candomblé, a partir da sua relação com o sagrado, tendo como mediador o espaço da arquitetura. Essa discussão é um desdobramento da tese do autor, em andamento, anterior à pesquisa de campo e, portanto, embasada no marco conceitual levantado. Como objeto empírico serão considerados os candomblés da Nação Ketu-Nagô, de língua iorubá.

\footnotetext{
* Felipe Ibiapina é Arquiteto e Urbanista, Doutorando da Universidade Federal de Pernambuco, ORCID <https://orcid.org/00000003-3087-6428>. Lúcia Leitão Autor é Arquiteta e Urbanista, Professora da Universidade Federal de Pernambuco, ORCID $<$ https://orcid.org/0000-00034935-2077>.
}

\section{A tríade relacional humano, espaço e sagrado na cosmovisão ocidental e nagô}

É ponto de partida obrigatório, sobretudo para os estudos afro-brasileiros, atentar para as divergências epistemológicas entre o pensamento ocidental, baseado na filosofia clássica e o pensamento nagô, não implicando, porém, em uma incompatibilidade. Conforme defendido por Sodré (2017), é possível uma comunicação transcultural, uma dialogia semiótica pautada na "lógica do trans ou do vaivém [...] que abrem caminho para novos termos das disputas de sentido" (SODRÉ, 2017, p.22-23).

Para alguns povos africanos, como os nagôs e os bantus, a pessoa é entendida em sua unidade com a comunidade, compreendendo que o corpo individual se integra à corporeidade da comunidade (SODRÉ, 2017). Baseada em Roger Bastide, Segato defende que "A pessoa humana é concebida como um agregado [...] em estado de 
1 De acordo com Barros (2009), a palavra "candomblé" parece ter se originado de um termo da nação Bantu, candombe, traduzido como "dança, batuque". Esta palavra se referia às brincadeiras, festas, reuniões, festividades profanas e também divinas dos negros escravos, nas senzalas, em seus momentos de folga, popularizando-se. Posteriormente, passou a denominar as liturgias que eles trouxeram de sua terra natal.

2 Manifestação de algo de 'ordem diferente' - de uma realidade que não pertence ao nosso mundo em objetos que fazem parte integrante do nosso mundo 'natural', 'profano' (ELIADE, 1992).

3 Trata-se, em suma, de uma ideia arcaica e muito difundida: a partir de um Centro projetam-se os quatro horizontes nas quatro direções cardeais. O mundus romano era uma fossa circular, dividida em quatro; era ao mesmo tempo a imagem do Cosmos e o modelo exemplar do hábitat humano [...]. O mundus era evidentemente equiparado ao omphalos, ao umbigo da Terra: a cidade (Urbs) situava se no meio do orbis terrarum (ELIADE, 1992, p.29).

4 Fustel de Coulanges (2002) chama atenção para o fato de cidade e urbe não estabelecerem para os antigos uma relação sinonímica. Enquanto a urbe dizia respeito ao domicílio, a cidade era tida como a associação política e religiosa de famílias e tribos. participação com o ambiente e seu passado. A unidade da pessoa, então, é ali um momento transitório de todos estes componentes" (SEGATO, 1995, p.24).

Uma das diferenças fundamentais entre a filosofia ocidental e a nagô é a recusa desta última em separar o que é intrínseco (o corpo) do extrínseco (o mundo). Isso repercute nas suas estruturas de representação. Enquanto a filosofia clássica/ocidental pautou sua visão de mundo na universalidade dos conceitos apreendidos por meio de reflexões abstratas do "espírito", desenvolvida no plano das essências, para os nagôs, "pensamento nenhum emerge exclusivamente das palavras [...] e sim principalmente da espacialidade instaurada pelo corpo em sua vinculação ao entorno ético e existencial, portanto na relação concreta entre homem e natureza" (SODRÉ, 2017, p.81).

Contudo, ainda que haja uma separação entre corpo e cosmos na visão da filosofia ocidental, não significa que haja uma indiferença ao papel do espaço perante a constituição da pessoa humana. Heidegger (1954/2010) explicita isso quando diz que "os mortais são, isso significa: em habitando têm sobre si espaços em razão de sua demora junto às coisas e aos lugares [...] mesmo fechando-se 'dentro de si mesmos', os mortais não deixam de pertencer à quadratura" (HEIDEGGER, 2010, p.08).

De acordo com Heidegger (1954/2010), para dar estância à quadratura o humano edifica lugares através da construção. "Construir recebe, a partir da quadratura, a medida para todo dimensionamento e medição dos espaços que se abrem, a cada vez, com lugares fundados" (HEIDEGGER, 2010, p.09). Através da construção, o humano dá significação ao cosmos, tornando possível a apreensão de um microcosmo, o mundo conhecido.

Nesse sentido, o humano, por meio de um ato criador - arkhé - que se consubstancia nos objetos edificados, funda lugares que inauguram espaços. "[...] o construir, porém, nunca configura 'o' espaço (heideggeriano) [...] assim é que, por produzir coisas como lugares, o construir está mais próximo da essência dos espaços e da proveniência essencial do espaço" (HEIDEGGER, 2010, p.08).

Na leitura de Vieira (2016) acerca da relação que o humano, enquanto mortal, estabelece com a quadratura, em Heidegger, lê-se: "[...] não há terra sem um céu que Ihe banhe de chuvas e ventos [...]; não há mortais sem uma terra que os acolha, material e existencialmente, enquanto morada [...]; e os acenos do divino só podem ser ouvidos pelos mortais [...]" (VIEIRA, 2016, 223).

A fim de fazer morada, o humano buscou suprimir o estado de caos que a imensidão do cosmos desconhecido imprimia, através do relacionamento com o divino, pelo ato da hierofania ${ }^{2}$. Durante a Antiguidade Clássica, a urbe assumia a posição de centro do mundo ${ }^{3}$ para os homens da cidade. Fustel de Coulanges (2002) explica que era erguido um altar para os deuses protetores - em geral, se tinha um único patrono - e sacerdotes eram encarregados de sacralizar o espaço através de rituais que se materializavam na demarcação territorial da urbe 4 . "Encerrada em limites sagrados, e estendendo-se em volta do altar, a urbe foi o domicílio religioso que abrigava os deuses e homens da cidade"

Para os iorubás (nagôs), o espaço da cidade também recebia o predicado de centro do cosmos. Todavia, ao contrário das urbes greco-romanas que eram independentes 
5 Baseia-se na definição de Geertz (2015, p.67) para religião: um sistema de símbolos que atua para estabelecer poderosas, penetrantes e duradouras disposições e motivações nos homens através da formulação de conceitos de uma ordem de existência geral e vestindo essas concepções com tal aura de fatualidade que as disposições e motivações parecem singularmente realistas.

\footnotetext{
6 É o espaço projetual, constituído por um vazio, que não deve ser confundido com o espaço pré-existente, que lhe dá o suporte físico-ambiental (LEITÃO; LACERDA, 2016).
}

entre si, do ponto de vista religioso, para o povo iorubá essa ideia de centralidade é compartilhada por diferentes reinos. Um dos mitos iorubás que tratam da formação do mundo dizem que "Oxalá se manifestou e tornou possível traçar as coordenadas do mundo, denominando-se ilê ifé e veio a ser o centro do mundo no qual se desenvolveram reinos, tribos, culturas e a existência" (BENISTE, 2006, p.25).

A cidade sagrada de Ifé está situada no estado de Osun, sudoeste da Nigéria. Foi um dos reinos do império iorubá, onde estão localizados os principais templos dedicados ao culto dos orixás Funfun - orixás da criação - tal como Obatalá e Odudua, par de divindades responsáveis pela criação do mundo (BARROS, 2009).

Para os adeptos dos cultos, cujo sistema simbólico religioso ${ }^{5}$ se erige em torno do culto aos orixás, as divindades habitaram, outrora, a terra - o plano da matéria, denominado aiyê - e viveram em uma África mítica. Ao contrário das crenças universalizantes, que pregam a conversão, os iorubás entediam que os deuses eram seus ancestrais divinizados e somente os membros do grupo, que compartilhavam laços consanguíneos, poderiam ser iniciados no culto (BASTIDE, 1978).

As últimas considerações são fundamentais para compreensão do candomblé enquanto cultura e religião, responsável pelo religare dos africanos escravizados no Brasil, e seus descendentes, com a ancestralidade africana, nos âmbitos material e espiritual - sem uma divisão bem delimitada, ambos os planos se relacionam e têm grande importância na vida do candomblecista (SODRÉ, 2017).

O candomblé teve, e ainda tem, um papel destacado na construção da identidade afro-brasileira, influenciando na formação subjetiva dos seus adeptos, o que repercute na constituição do sujeito, tendo como desdobramento a forma como a pessoa se relaciona como espaço e como se estabelece a tríade humano, espaço (arquitetônico) ${ }^{6}$ - onde o humano se demora - e sagrado, que está sendo investigada.

Apesar de ter sua matriz nos cultos africanos - no caso estudado, os orixás do panteão iorubá -, o candomblé surge da confluência dos sistemas simbólicos de diferentes grupos que se unem para formar uma religião que permita dar continuidade às práticas da sua ancestralidade comum. Para tal, algumas adaptações foram necessárias, como condição para o ingresso no culto que, originalmente famíliar, por mérito de sangue, adota o "chamado do orixá" como novo critério (BASTIDE, 1978). O processo de iniciação e a integração à comunidade do candomblé marcaria uma passagem, alterando a relação da pessoa no espaço, em função da dimensão do sagrado que se erige pela cosmovisão afro-brasileira. Isso significa que, mesmo tendo nascido brasileiro, e crescido em uma sociedade ocidental, o sujeito incorpora, através da religião, novas identificações, se aproximando da visão de mundo nagô.

\section{O Espaço, o Humano e o Sagrado no terreiro de candomblé}

Por religião entende-se uma sistematização de postulados ideológicos (crenças) e práticas (ritos) relativas às coisas sagradas que congrega indivíduos, originando uma comunidade formada pelos crentes da mesma fé e seus sacerdotes, o que Durkheim (2008) denomina Igreja. Adaptando essa definição para o candomblé, pode-se dizer que este consiste em um sistema simbólico religioso que congrega pessoas - a noção 
7 Essa comunidade, que inaugura uma experiência inédita no interior de um ordenamento social hegemônico, implica um novo tipo de subjetivação, em que ocupam um primeiro plano a experiência simbólica do mundo, o primado rítmico do existir, o poder afetivo das palavras e ações, a potência de realização das coisas, as relações interpessoais concretas, a educação para a boa vida e para a boa morte, o paradigma comunitário, a alegria frente ao real e o reconhecimento do aqui e agora da existência. Este último traço deixa manifesto, principalmente, que essa subjetividade não tem no pescoço a corda teológica, nem os pés fincados na presunção da eternidade (SODRÉ, 2017, p.100)

8 Axé é a força vital e sagrada que está presente em todas as coisas que a natureza produz; grande fonte de poder que é mantida, ampliada e renovada por meio dos ritos que se processam nos candomblés (MATOS, 2019, p.252).

9 Para a fundação de um terreiro de candomblé, cumpre-se o ato de plantar o axé do terreiro, responsável por sacralizar o espaço (MATOS, 2019).

10 laô ou lyawó é um termo iorubá que significa, literalmente, "a esposa". Refere-se ao recém iniciado no Candomblé, seja do sexo feminino ou masculino. Especula-se que o termo iaô, esposa, esteja relacionado com a atribuição simbólica de convento para o terreiro de candomblé, uma vez que, na Igreja Católica - religião que manteve um sincretismo histórico com o Candomblé - os conventos são os lugares onde as noviças se preparam para desposar Cristo e seguir uma vida religiosa.

11 Raffestin (1993) compreende o território como o palco das relações, um "lugar de poder", que se configura através de processos de troca ou comunicação definidos por uma combinação de fluxos de energia e informação. Todo território pressupõe uma demarcação no espaço que pode se dar de modo físico ou abstrato, fixo ou circunstancial - variações materiais e temporais que decorrem da espécie de relação que se estabelece e funda o território. de pessoa no candomblé abrange, além do indivíduo, sua ancestralidade --, originando uma comunidade hierarquizada formada por filhos(as)-de-santo e um(a) pai(mãe)-desanto, denominada terreiro de candomblé.

Os terreiros de candomblé são instituições religiosas independentes, o que significa que, apesar das filiações e das raízes culturais compartilhadas por diferentes terreiros, cada um é autônomo, o que repercute na configuração dos espaços - o arranjo espacial das construções, bem como o partido e o programa arquitetônico -, das práticas e das normas de conduta que acabam acomodando-se entre a linhagem do fundador do axé e o perfil do dirigente espiritual.

Dois termos em iorubá são evocados para designar o terreiro de candomblé, a partir de âmbitos distintos. Sodré (2017) define a egbé ${ }^{7}$ como a comunidade litúrgica que se erige em torno do culto, abrangendo as relações socioculturais que os indivíduos estabelecem nesse contexto. 0 /lê $A x e^{8}$, em tradução direta do iorubá para o português, significa casa do axé, ou casa da força, referindo-se à casa de culto, enquanto espaço sagrado ${ }^{9}$ referente à instituição religiosa.

É no âmbito do llê Axéque a pesquisa de doutorado, do qual este artigo é subproduto, está ancorada. A etimologia desse termo que designa terreiro, aponta para a casa - Ilê - enquanto espaço simbólico. A nomenclatura dos vínculos dos membros do terreiro, filhos-de-santo, irmãos-de-santo, pai-de-santo, mãe-de-santo, reforça o caráter familiar que estrutura a comunidade religiosa e a significação subjetiva de casa que o espaço assume.

Bastide (1978) destaca que além da função de casa (no estrito de abrigo), o terreiro assume o caráter de templo e de convento. Entende-se como templo por abrigar objetos litúrgicos e ritualísticos, bem como os assentamentos dos deuses - suas representações simbólicas imantadas pelo axé, materializadas em pedras e pedaços de ferro -. O convento se configura simbolicamente em razão das iniciações no culto, onde os fiéis se mantêm reclusos durante o período aproximado de uma quinzena, onde executam rituais específicos, próprios da sua formação enquanto ia ${ }^{10}$.

Cumpre destacar que o terreiro de candomblé contribuiu para a reterritorialização da ancestralidade africana concernente à comunidade afro-brasileira, a partir da delimitação de um território ${ }^{11}$ simbólico, sob o que qual se edificou uma África mítica no solo brasileiro, "uma 'África qualitativa' que se faz presente, condensada, reterritorializada" (SODRÉ, 1988, p.52-53).

Sodré (1988) destaca que o terreiro de candomblé não tem por intento negar a ordem sociocultural estabelecida, materializada na cidade, que foi erigida a partir dos critérios ocidentais, pautados em modelos europeus. Mas, tem por escopo propiciar aos iniciados no culto, uma experiência centrada na cosmovisão africana - no caso, nagô. Apesar de estar localizado na cidade - no caso dos terreiros urbanos -, o terreiro de candomblé funda uma nova África, a partir do território e do espaço simbólico do terreiro.

O território-terreiro comporta diferentes dimensões do poder que funda a egbé comunidade religiosa - e se instala no ilê axé - o espaço físico, arquitetônico, do terreiro. Para compreender a origem desse poder é preciso adentrar na dimensão cultural, sustentada pela herança que o humano recebeu dos antepassados ao longo 
12 Descendentes diretos de africanos. Os primeiros terreiros de candomblé foram fundados por afrodescendentes, mantendo a linhagem sanguínea do culto em África. As gerações posteriores, já miscigenadas eram compostas por afro-brasileiros e, até mesmo, brancos. de toda a história, atribuindo aos rituais a função precípua de garantir a sustentação da vida (SIQUEIRA, 2018).

O humano funda seus territórios sagrados a fim de orientar sua relação com o firmamento, a superfície terrestre, e o seu lugar diante do universo desconhecido. Os diferentes povos erigiram estruturas explicativas para a cosmogonia - teoria especulativa sobre a origem do universo. A cosmogonia parte de um mito que é recontado, ao próprio modo, nas diferentes religiões (ELIADE, 1992).

Na mitologia iorubá, Olorum é o Deus supremo, eterno e anterior a todas as coisas, deu origem a si mesmo e ao universo. Portador do axé primordial - força, energia que move a tudo e a todos, essência intangível-, Olorum cria os Irunmolés, seres divinos com os quais ele divide o seu axé e a incumbência da criação (BARROS, 2009). Dentre os irunmolés destacam-se Exu, Obatalá e Odudua, estes últimos formam o casal divino primitivo, "representado por duas metades de cabaça, fechadas uma sobre a outra [o igbadu, a 'cabaça da vida'] uma figurando a abobada celeste [Obatalá], a outra a terra a ser fecundada [Odudua]" (BASTIDE, 1978, p.80).

"Quando Olorum decidiu dar criação à existência, ao se mover e sair da inércia, fez surgir Exu, o ser criado para trazer mobilidade e a evolução! A partir de Exu, Olorum criou os demais irunmolés [...]" (BARROS, 2009, s/p), intermediários entre os homens e Olorum, denominados pelos iorubás como orixás. Estas divindades são responsáveis pela regência dos diferentes aspectos da criação e o axé compartilhado por eles forma a natureza. Além de se fazerem presentes nos elementos naturais, a história da criação conta que eles caminharam na África Mítica, berço da humanidade, e, hoje em dia, visitam a terra mediante os rituais que culminam na incorporação dos seus filhos nos terreiros de candomblé que são, em essência, um microcosmo da terra ancestral (BASTIDE, 1978).

O microcosmo erigido pelo terreiro pode ser examinado a partir de duas dimensões: o território e a arquitetura (espaço construído). Integrada ao território, a arquitetura do terreiro é erigida para dar estância ao Ser, permitindo o habitar dos descendentes de africanos que no Brasil se estabeleceram. Dialogando com Heidegger (1954/2010), Velame (2019) destaca que o habitar, através do terreiro de candomblé, se transforma no caráter fundamental do Ser - afrodescendentes e afro-brasileiros ${ }^{12}$ -, de acordo com os quais os ara-aiê (mortais) são no aiê (terra; plano material).

\section{A dimensão arquitetônica do terreiro de candomblé}

A perspectiva teórica coadunada considera a arquitetura a partir da sua dimensão espacial, tendo como "protagonista" do fato arquitetônico o espaço interior que, segundo Zevi (2009), só pode ser conhecido e vivido através da experiência direta, do contato direto entre os sujeitos e o objeto, o humano e o espaço.

O tempo, apontado por Zevi (2009) como quarta dimensão da arquitetura, relaciona-se diretamente com a percepção humana, uma vez que reúne os ângulos dos deslocamentos do humano no espaço, na medida em que este "se demora". A dimensão temporal estaria mais próxima da concepção espacial heideggeriana, ao contrário das demais, métricas - comprimento, altura e largura - que constituem o espaço cartesiano. 
Cumpre ressaltar que, ao considerar o protagonismo do espaço, não se pode negligenciar os demais valores constituintes de uma edificação. Como destaca Zevi (2009, p.26), ainda que o espaço seja o "substantivo da arquitetura, não é suficiente para defini-la".

$\mathrm{Na}$ arquitetura do terreiro de candomblé, objeto deste estudo, a perspectiva estética deve ser lida de forma ampliada. Geertz $(2015$, p.82) pontua que, em geral, a atitude estética tende à "suspensão do realismo ingênuo e do interesse prático no fato de que, em vez de questionar as credenciais da experiência cotidiana, simplesmente se ignora essa experiência em favor de uma insistência ávida nas aparências". Já a perspectiva religiosa, para este autor (2015), busca o verdadeiramente rea/ por meio do seu sistema simbólico.

O sistema simbólico religioso é formado por duas instâncias que se traduzem nos conceitos de cosmovisão e ethos. O primeiro diz respeito à visão de mundo dos sujeitos que compartilham do sistema religioso, tal como sua percepção acerca da realidade, no que tange à natureza das coisas, desenvolvendo no âmago da cultura conceitos próprios de natureza, da sociedade e de si mesmo. Em suma, a cosmovisão reúne os aspectos cognitivos e existenciais. O ethos, por sua vez, corresponde aos aspectos morais e estéticos. Juntos, cosmovisão e ethos erigem os símbolos sagrados (GEERTZ, 2015).

Matos (2019) destaca que no terreiro de candomblé o simbólico está ancorado na dimensão do lugar, enquanto locus de relações identitárias acompanhadas do sentido de pertencimento da egbé. Assim, o significado simbólico da arquitetura e dos elementos materiais que erigem o complexo simbólico do llê Axé não se encerra no nível espacial, associando-se, necessariamente, ao território.

13 A edificação de quartos ou casas para os santos vai depender da dimensão do terreno, bem como das condições econômicas da comunidade.

\footnotetext{
14 Nos assentamentos dos quartos (ou casas)- de-santo, acredita-se que as divindades se fazem presente. Não se trata de um simbolismo enquanto sistema de representação de algo, mas, a materialização desse algo no elemento físico referenciado. Por exemplo, se o assentamento de Xangô - o Orixá da justiça - for composto por um pote de barro com pedras, dentre outros elementos ritualísticos, significa que a matéria assentada é o próprio Xangô. A energia de Xangô está naquele espaço arquitetônico, não é como a imagem de um santo católico - iconografia - na Igreja que inspira a devoção, mas, não se confunde com o santo em si.
}

Para fundar um terreiro é necessário, mais do que edificar, fazer morada, ação que, para o humano religioso, vem acompanhada da sacralização do espaço. Somente após os rituais de consagração, com a implantação do axé, é que o terreiro passa a existir como tal. "Portanto, o axé do terreiro - que consiste fundamentalmente no axé do chão, da cumeeira e da divindade patrona da casa, que juntos dão origem ao axé comunal - constitui o principal patrimônio de uma casa de candomblé [...]" (MATOS, 2019, p.222).

A tipologia e o programa arquitetônico dos terreiros seguem mais ou menos um padrão, de acordo com as raízes culturais do culto. O programa genérico dos espaços rituais do candomblé adere ao esquema composto por barracão, cozinha e casas (ou quartos)-de-santo ${ }^{13}$. O barracão é o espaço onde ocorrem as celebrações, é onde os iniciados incorporam as divindades para o xirê, a dança ritual. A cozinha, também é entendida como espaço ritualístico onde se preparam as comidas dos santos que servirão como oferenda e serão depositadas nas suas respectivas casas (ou quartos)-de-santo, local onde estão assentadas estas divindades ${ }^{14}$.

Para este ensaio, se estabelece como recorte analítico da arquitetura do candomblé o barracão. A escolha não indica uma superioridade hierárquica deste com relação aos demais espaços, uma vez que todos encontram-se integrados e têm sua importância para o terreiro. Mas, pelo fato de ser sob o barracão que o axé principal está firmando, assumindo, assim, uma centralidade simbólica no espaço construído. 


\section{O barracão}

O axé é o poder em torno do qual está erigido o território sagrado do terreiro, onde o candomblecista faz morada, ao tempo que constrói o ilê axé, a casa do axé. O centro gravitacional desse microcosmo criado à imagem de uma África mítica é o barracão, espécie de salão, que contém um eixo, em geral marcado por um pilar - quando não tem o pilar, costuma haver uma marcação no piso- sob o qual está enterrado o axé do chão, e sobre o qual, no ponto mais alto da coberta, está assentado o axé da cumeeira. Esses axés se comunicam com os demais espaços da casa (SANTOS, 2012).

O eixo central do barracão corresponde ao que Eliade (1992) denomina axis mundi - também chamado pilar cósmico e coluna universal -, elemento responsável por conectar o "céu" e a "terra" (plano espiritual e material). O simbolismo do axis mundi está presente em diversos sistemas religiosos tradicionais, seja sob a forma do pilar ou de uma coluna, árvore, escada, montanha que pudesse representar o ponto de conexão entre os planos existenciais o que, por conseguinte, marcaria o "umbigo do mundo", o eixo do cosmos segundo determinado sistema cultural.

Outrossim, a arquitetura participa da cosmogonia do povo de candomblé, uma vez que recria a estrutura do cosmos no seu espaço, servindo de palco para a atualização da mitologia dos orixás, performando as histórias recontadas pelos antepassados de uma África mítica, onde deuses viviam entre os homens, amavam, guerreavam, enfim, mantinham relações afetivas. Estes mesmos deuses, apesar das paixões humanas, representavam também os domínios da natureza (BASTIDE, 1978).

O solo é a terra, o teto é o céu; entre as duas divindades, os Orixá imitam com sua mímica a vida dos elementos da natureza, a tempestade que se desencadeia (lansã), o ziguezague do relâmpago (Xangô), o murmúrio dos regatos (Oxum), as vagas do oceano (lemanjá), e também as ações dos homens que vivem no mundo - os caçadores (Oxosse), ferreiros (Ogum), ou a passagem das doenças epidêmicas (Omolu); o salão de dança é então o microcosmo, ou também, o mundo reconstruído em sua realidade mística, que é a sua verdadeira realidade. (BASTIDE, 1978, p.84)

É no espaço arquitetônico do barracão que acontece o xirê, a dança ritual dos orixás, - Na fotografia (Figura 1) tem-se o registro de um xirê que aconteceu em um terreiro de nação Ketu, localizado no estado de Pernambuco, objeto empírico da tese do autor -. Para que os deuses, acostumados a pisar no solo africano, viessem a descer nestas terras no além-mar africano, foi necessário instituir rituais para lhes render sacrifícios e oferendas. Com o tambor alimentado pelo sangue, seguem os toques para atrair os orixás. Os seus filhos-de-santo rodopiam em torno do poste central do barracão (pilar cósmico) - no caso do terreiro da Figura 1 não existe um pilar real, mas o seu eixo está simbolizado através de uma marcação no piso, a partir da qual as pessoas se orientam - e é por conta desse dínamo que conecta a dimensão espiritual (orun) à dimensão material (ayiê) que os orixás baixam (incorporam) nos seus cavalos (filhosde-santo) - daí a expressão baixar o santo (BASTIDE, 1978).

A África - berço da ancestralidade dos candomblecistas da qual seus antepassados foram arrancados compulsoriamente e escravizados - é recriada, simbolicamente, no terreiro. Diante do trecho escrito por Bastide (1978, p.16), em que o autor assinala 


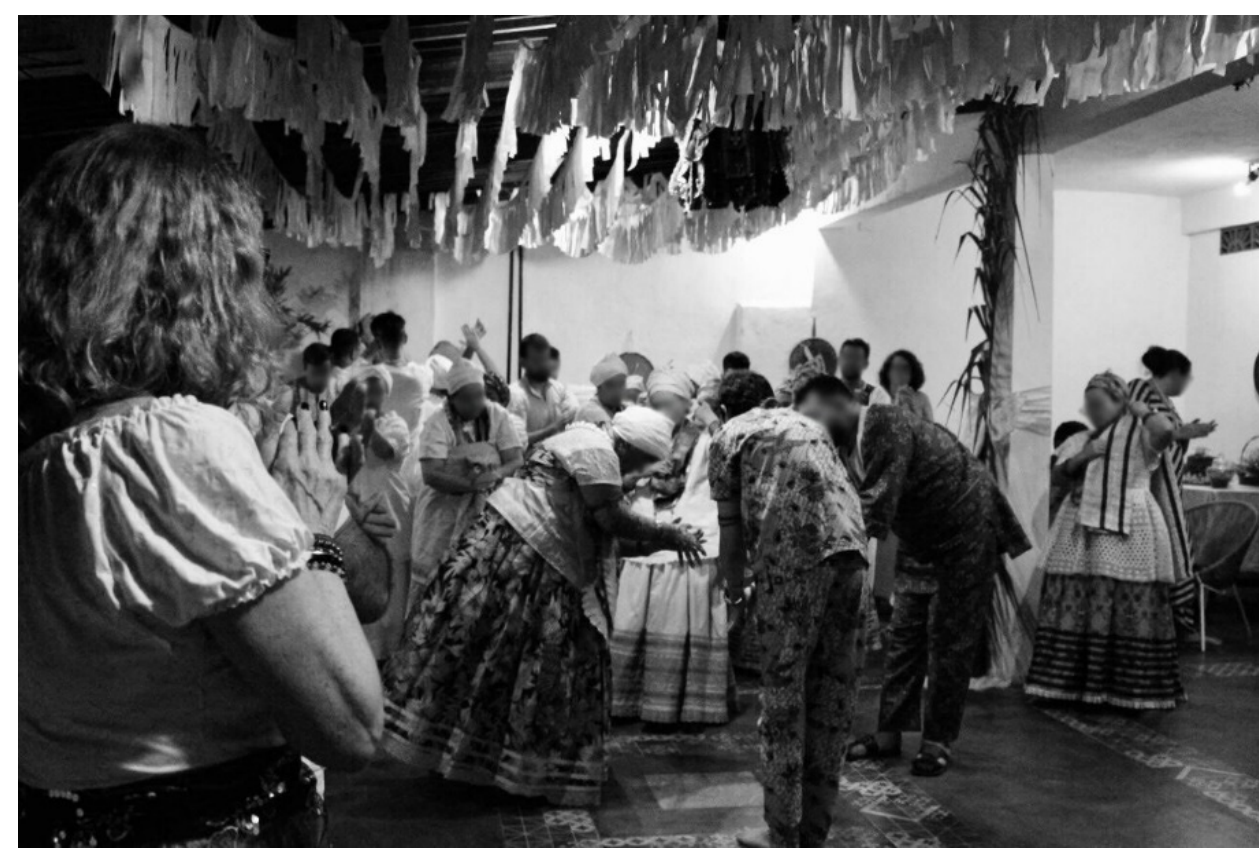

Figura 1: Xirê no barracão do llê Axé Ayrá Omin Funfun. Fonte: Ibiapina (2019), acervo do autor

\footnotetext{
15 Não é difícil encontrar essas ligações. Elas consistem nas relações entre o desamparo da criança e o desamparo do adulto, que é continuação daquele, de modo que, como seria de se esperar, a motivaçãopsicanalítica para a formação da religião se transforma na contribuição infantil à motivação manifesta dessa formação. Quando então o adolescente percebe que está destinado a ser sempre uma criança, que jamais poderá prescindir de proteção contra poderes desconhecidos, empresta-lhes os traços da figura paterna, cria os deuses, dos quais tem medo, que procura agradar, e aos quais, no entanto, confia a sua proteção (FREUD, 2018, p.43-44).
}

que durante o xirê "apagou-se o tempo da escravidão", entende-se que, naquele momento, por abrigar em seus corpos uma corte divina, os homens e mulheres incorporados são destituídos da condição de descendentes de escravos e recuperam o posto na realeza espiritual.

"Não se trata da nostalgia do antigo [...]. Trata-se, sim, de um eterno retorno ou um eterno renascimento, um logos circular (o fim é a origem, a origem é o fim), que se subtrai às tentativas puramente racionais de apreensão enquanto algo fundamental de que não se recorda nem se fala, mas não falta, pois se simboliza no culto [...] aos princípios cosmológicos (os orixás, as divindades) e aos ancestrais. (SODRÉ, 2017, p.97)

Sendo a religião uma criação humana que, para Freud (1927/ 2018), se dá como uma reação à angústia do desamparo - condição existencial que acompanha o humano desde o nascimento ${ }^{15}$-, ela age na fusão entre o mundo imaginário e o vivido, por meio dos sistemas simbólicos, dando origem a um mundo único. "Qualquer que seja o papel que a intervenção divina possa ou não exercer na criação da fé [...] ele está, pelo menos basicamente, fora do contexto dos atos concretos de observância religiosa que a convicção religiosa faz emergir no plano humano" (GEERTZ, 2017, p.82-83).

Pela crença, durante o ritual que acontece no espaço do barracão, uma conexão com o orun, plano sobrenatural, é estabelecida e os deuses se manifestam. Através da vinda dos orixás, o axé é renovado, trazendo bençãos para os presentes. O culto, dentro desse sistema cultural, é visto como uma ação fundamental para a manutenção da vida, uma vez que a vida é constituída de axé e, apesar da natureza dispor de axé nos seus elementos, apenas rituais podem despertar essa força, com o auxílio dos orixás (MATOS, 2019, p.252). 
O habitar do candomblecista junto à egbé, a medida que dá estância à quadratura - terra, céu, humano, divindade - confere à edificação um significado maior do que o real - material. "[...] O seu valor não se encontra relacionado apenas ao ritual de consagração a que foi submetida, mas também à história que antecedeu sua sacralização" (MATOS, 2019, p.199). "Cada uma das suas partes expressa um sentido próprio, mas, em conjunto e ao tempo em que incorpora a dimensão material, a arquitetura torna-se um suporte no qual o sagrado se revela" (MATOS, 2019, p.201).

Em suma, a arquitetura tem uma participação fundamental no processo que conecta o humano com o sagrado. Muito além de abrigar os rituais, a construção consubstancia a relação que o candomblecista estabelece no solo sacralizado, o território-terreiro que recria a África mítica.

\section{Considerações Finais}

Diante do exposto, é factível validar a tríade relacional constituída pelo humano, o Espaço (arquitetônico) e o Sagrado, no candomblé, uma vez que, a formação identitária da pessoa, no contexto do candomblé nagô, perpassa a comunidade egbé - e a ancestralidade - o culto aos antepassados -, emergindo a necessidade de se criar em solo brasileiro um lugar que possa abrigar as relações entre os sujeitos, e destes com o divino ancestral, o que se dá a partir de uma convivência que se nutre no território-terreiro.

No encalço da proposta epistemológica de estabelecer uma ponte entre a filosofia ocidental, heideggeriana, e a nagô, para dar estância à quadratura o humano constrói, e assim, se demora. O llê Axé, a casa que resguarda o axé, que é o princípio do terreiro, é a principal morada do candomblecista. É no vazio da arquitetura que os corpos se movimentam em transe, a família de santo se saúda e confraterniza com os deuses que descem no recinto para caminhar no mundo e, assim, está firmada a quadradura na África mítica - o humano, mortal, o céu e a terra, construídos no barracão, através do simbolismo do pilar cósmico, e as divindades, os orixás que, convidados pelos toques dos atabaques, encontram pouso no llê.

Diante dessa lógica, a arquitetura se apresenta como indispensável para viabilizar a conexão entre o Humano e o Sagrado, uma vez que o terreiro prescinde de um Espaço construído, uma arquitetura erguida no território sacralizado, cuja materialidade se funde à imaterialidade através dos significados impressos pelo sistema simbólico, que se revela na estética e na espacialização dos corpos durante os rituais.

\section{Referências bibliográficas}

BARROS, Marcelo. O candomblé bem explicado (Nações Bantu, lorubá e Fon). Rio de Janeiro: Pallas, 2009. E-Book. ISBN 978-85-347-0576-9

BASTIDE, R. O candomblé da Bahia. São Paulo: Companhia das Letras, 1978.

BENISTE, José. Mitos Yorubás: o outro lado do conhecimento. Rio de Janeiro: Bertrand Brasil, 2006.

COULANGES, Fustel de. A Cidade Antiga. trad. Pietro Nassetti. Martin Claret, São Paulo, 2002 
DURKHEIM, Emile. As Formas elementares de vida religiosa: o sistema totemico na Australia. São Paulo: Paulus, 2008.

FREUD, Sigmund. O futuro de uma ilusão. trad. Renato Zwick. Porto Alegre: LPM, 2018.

GEERTZ, Clifford. A interpretação das culturas. Rio de Janeiro: LTC, 2015, p.67.

HEIDEGGER, Martin. Construir, habitar, pensar. In: Ensaios e Conferências. trad. Emanuel Carneiro Leão, Gilvan Fogel, Márcia Sá Cavalcante Schuback. Petrópolis: Vozes, 2010.

LEITÃO, Lúcia; LACERDA, Norma. O espaço na geografia e o espaço na arquitetura: reflexões epistemológicas. Caderno das Metrópoles. v.8. n.37. São Paulo, 2016. p. 803-822.

LODY, Raul. O povo de Santo: religião, história e cultura dos orixás, voduns, inquices e caboclos. Coleção Raízes. 2.ed. São Paulo: Martins Fontes, 2006.

MATOS, Denis. A casa do Velho: o significado da matéria no candomblé. Salvador: EDUFBA, 2019.

RAFFESTIN, Claude. Por uma Geografia do Poder. trad. Maria Cecília França. São Paulo: Ática, 1993.

SANTOS, Romário Oliveira. Moradas do sagrado: lugares e edificações dos cultos afro-brasileiros no Planalto Central. In: Instituto do Patrimônio Histórico e Artístico Nacional (Iphan). Superintendência do Iphan do Distrito Federal. Terreiros do Distrito Federal e Entorno: inventário Nacional de Referências Culturais. Coordenação de Giorge Bessoni, Rodrigo Ramassote e Marcelo Reis. Brasília, DF: Iphan-DF, 2012. p. 65-106.

SEGATO, Rita. Santos e Daimones. Brasília: Editora da Universidade de Brasília, 1995.

SIQUEIRA, Felipe. Territorialidades Sagradas: religiosidades católica e afro-brasileira na Zonta Norte de Teresina (PI). Dissertação (Mestrado em Geografia) - Universidade Federal do Piauí, Teresina, 2018.

SODRÉ, Muniz. O terreiro e a cidade: a forma social negro-brasileira. Petrópolis, Vozes, 1988. Pensar Nagô. Petrópolis: Vozes, 2017.

VELAME, Fábio. Arquiteturas da ancestralidade afro-brasileira: O Omo llê Agboulá: Um templo do culto aos Egum no Brasil. Salvador: EDUFBA, 2019.

VIEIRA DO NASCIMENTO, J. V. . A coisalidade da coisa e a quadratura em Martin Heidegger. Peri , v. 08, 2016.

ZEVI, Bruno. Saber ver a arquitetura. trad. Maria Isabel Gaspar, Gaëtan Martins de Oliveira. 6.ed. São Paulo: Editora WMF Martins Fontes, 2009. 